\title{
IDŐJÁRÁS
}

Quarterly Journal of the Hungarian Meteorological Service

Vol. 122, No. 2, April-June, 2018, pp. 145-158

\section{Extreme precipitation events in the Polish Carpathians and their synoptic determinants}

\author{
Agnieszka Wypych ${ }^{1}$, Zbigniew Ustrnul $^{2}$, Danuta Czekierda ${ }^{2}$, \\ Angelika Palarz ${ }^{1}$, and Agnieszka Sulikowska ${ }^{1}$ \\ ${ }^{1}$ Department of Climatology, Jagiellonian University, \\ 7 Gronostajowa Str., 30-387 Krakow, Poland \\ ${ }^{2}$ Institute of Meteorology and Water Management - National Research Institute, \\ 61 Podlesna St., 01-673 Warszawa, Poland
}

*Corresponding author E-mail: agnieszka.wypych@uj.edu.pl

(Manuscript received in final form February 1, 2017)

\begin{abstract}
Heavy rainfalls and consequent floods are the most important extreme events in Central Europe in terms of frequency and economic losses. The purpose of the study is to evaluate regional extreme precipitation events in the Polish Carpathian Mountains as well as to determine the circulation basis for these events. Extreme precipitation values were identified based on daily precipitation totals measured at almost 70 weather stations in the Polish Carpathians between 1951 and 2015. The analysis concentrates on daily mean areal precipitation totals in excess of $100 \mathrm{~mm}$ per day as well as 50 and $30 \mathrm{~mm}$, which causes flooding in the Carpathians. All extreme precipitation data were analyzed from a synoptic perspective, with special attention paid to pressure patterns over Central Europe. The analysis confirms that the heaviest rainfalls are affected by the situations with the $\mathrm{N}$ NE airflow. However, analyses with the application of the upper tropospheric data brought some new findings on the precipitation extreme topic. It turned out that most cases with significant rains occurred when the mid-tropospheric advection was from the southern sector (during the typical $\mathrm{N}$ and $\mathrm{NE}$ advections in the lower part).
\end{abstract}

Key-words: precipitation totals, extremes, atmospheric circulation, Carpathians 


\section{Introduction}

Atmospheric precipitation is a meteorological element which is most often mentioned as the cause of many environmental and socio-economic extreme phenomena. In Central Europe, especially in southern Poland, south-eastern part of Germany, in Czech Republic, and Slovakia, these are floods of different range. Therefore, the most important in this case is considering extremely high precipitation totals.

The discussion on extremely high precipitation belongs to the most important tasks when meteorological extreme phenomena become an issue. Moreover, as most climatic elements in the temperate zone, also atmospheric precipitation is considerably determined by circulation factors and depends mainly upon the direction and type of oncoming air masses. The topic is relatively well expressed in the literature. It especially concerns the values forcing floods and high waters. Most publications concern the studies of the circulation background of rainfalls in mountains, with dangerous effects of the high totals (i.e., Cebulak, 1992; Cebulak and Niedźwiedź, 2000; Ustrnul and Czekierda, 2001; Niedźwiedź, 2003; Mudelsee et al., 2004; Brázdil et al., 2005; Niedźwiedź et al., 2009, Kundzewicz et al., 2012; Łupikasza and Niedźwiedź, 2015, Niedźwiedź et. al, 2015, Łupikasza, 2016 ), some of them are with special attention to considerable floods dated July 1970 (Morawska-Horawska, 1971), July 1997 (Pavlik and Sandev, 1997), and May 2010 (Bissoli et al., 2011; Kašpar et al., 2013). There are also publications treating the issue of extreme flood comprehensively with all the hydrological, environmental, as well as socio-economical results (e.g., Müller et al. 2009), flood monographs of 1997 and 2010 (Grela et al., 1999; Maciejewski et al., 2011) with the latest publication describing flood risk in Europe (Kundzewicz, 2012) or in upper Vistula river basin (Kundzewicz et al., 2016).

The purpose of the paper is to evaluate regional extreme precipitation events taking place over the course of the last several decades as well as to determine the circulation basis for these events in the Polish Carpathians, a great part of which belongs to the Western Carpathian Mountains. That area is regarded as the primary source area of dangerous floods in Poland (Niedźwiedź et al., 2015, Twardosz et al., 2016, Kundzewicz et al., 2016). Given that most extreme precipitation events cause floods and high waters, one purpose of the paper is also to describe the circulation determinants of these extreme hydrological events.

\section{Material and methods}

The area of interest - located in Poland - covers about $80000 \mathrm{~km}^{2}$ (Fig. 1) and is distinguished by very differentiated hypsometry: from lowland landscape on the north, through highlands and foothills, up to the highest tops of the Tatra Mountains (over $2600 \mathrm{~m}$ a.s.1.) a bordering range with Slovakia. The altitude reaches $350 \mathrm{~m}$ a.s.l. on average, however, the region is famous for its diverse 
elevation. Therefore, climatologically, Polish Carpathians are also the most complex area in Poland. Their relief features are important in the formation of their local weather conditions and climate patterns. The mountains constitute the latitudinal orographic barrier, which is additionally forcing the condensation of the water vapor.

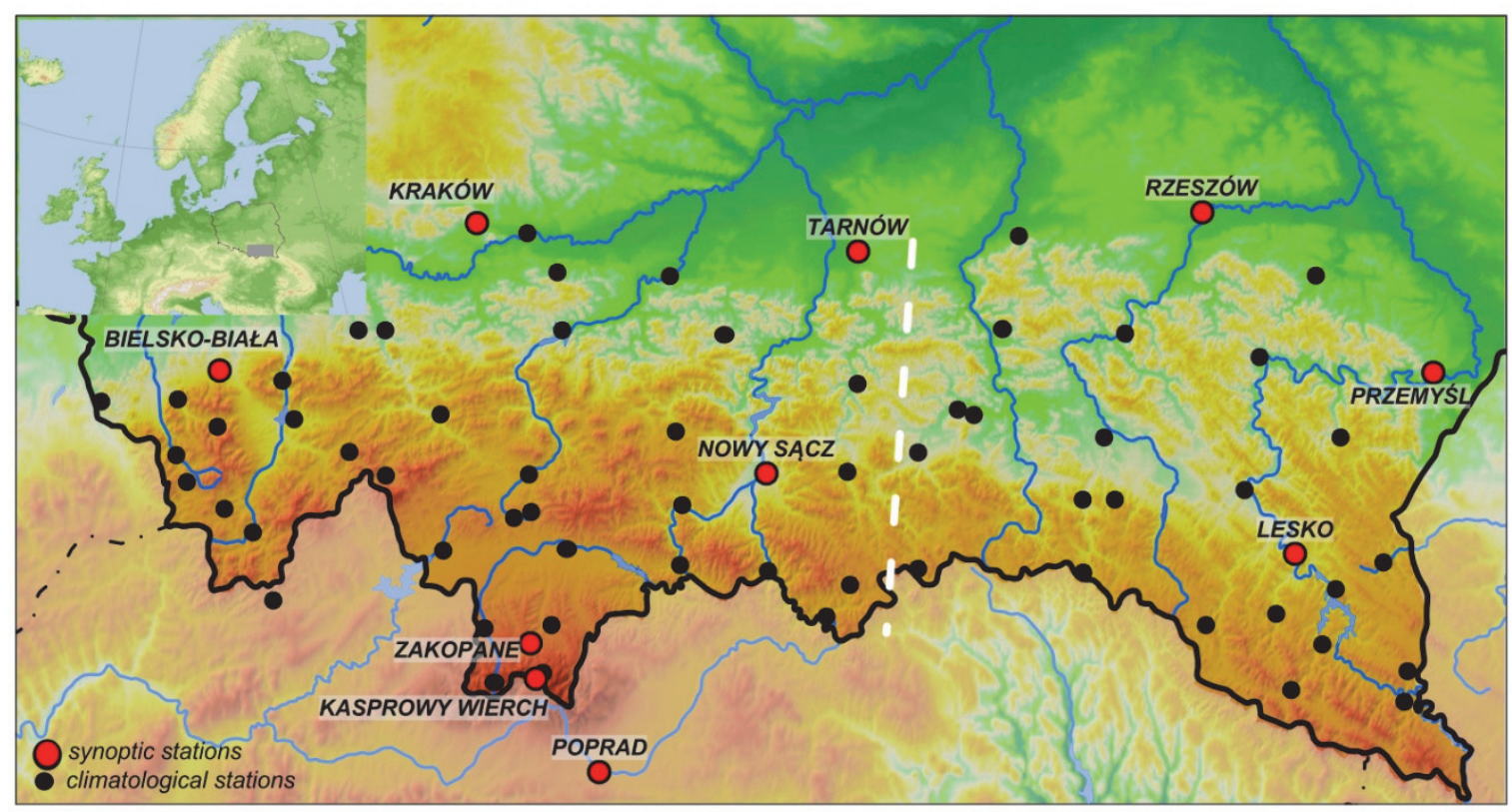

Fig. 1. Location of measuring points mentioned in the study (dashed line: virtual border between the western and eastern parts of the Carpathians).

Daily precipitation totals from almost 70 measuring points (synoptic as well as climatological stations from the Polish Carpathians territory) were taken into account (Fig. 1). Two other stations - for validation purposes - have been also taken from the Slovak side of the Western Carpathians. The main research material was based on data from the 65-year period of 1951-2015. This period covers the longest time horizon, for which it was possible to create homogenous meteorological observation series. Precipitation totals have been thoroughly checked, not only in a formal sense, but also in spatial terms where necessary. Needless to say, the issue of measurement data homogeneity is crucial in any analysis of climate issues. Even the slightest errors in the used data, which are often undetectable by standard control procedures, can lead to completely false conclusions. This also applies to issues where extreme values are estimated. Special care needs to be taken when analyzing such data, and, in fact, special efforts were made to make sure that the data used herein are error free. 
While examining extremes, including precipitation extremes, a question about their unique nature emerges. It needs to be stated, when the extreme threshold is only a local or regional one and when, reaching certain magnitude, it can become worldwide. Therefore, weather extremes as well as precipitation extremes should be discussed at first at a regional or even local scale, where they are the most important due to their influence.

The paper focuses on daily mean areal precipitation totals in excess of 50 $\mathrm{mm}$ per day as well as $30 \mathrm{~mm}, 10 \mathrm{~mm}$, and $5 \mathrm{~mm}$ over the course of two or three days of continuous precipitation, which causes flooding in the Carpathians. Also the incidents of daily precipitation totals over $100 \mathrm{~mm}$ at selected stations were taken into account. The paper analyzes long-term variability in flooding patterns. All extreme precipitation data were analyzed from a synoptic perspective, with special attention paid to pressure patterns over Central Europe. Therefore, Grosswetterlagen classification (Werner and Gerstengarbe, 2010) was included because of its widespread use in Europe and the possibility to refer the obtained results to other international research and local circulation types classification by Niedźwiedź (2016), which has been proved to be useful in research conducted for the Western Carpathians (Cebulak, 1992; Niedźwiedź et al., 2015). A detailed description of the types of circulation for each of the used calendars is provided in the works cited, whereas a summary of the circulation types for each of the two schemes is provided by Ustrnul and Czekierda (2009).

Simultaneously, other relevant data and materials have been used. Above all, the data on air mass advection defined on the basis of the data from NCEP/NCAR reanalyses for several grid points from the area of interest. Special attention was paid to the data originating from the grid point $50^{\circ} \mathrm{N}$ and $20^{\circ} \mathrm{E}$. Basing on this data, the directions and strength of airflow at upper atmospheric levels $(850,700$ and $500 \mathrm{hPa}$ ) were determined. Finally, additional synoptic materials (e.g., charts, aerological diagrams, etc.) have been used and studied.

The crucial part of calculations consisted of the analysis of the frequency of occurrence of daily precipitation totals in particular ranges, i.e., over $5 \mathrm{~mm}, 10 \mathrm{~mm}$, $20 \mathrm{~mm}$, and $30 \mathrm{~mm}$. The sums constituted the so-called mean areal precipitation was calculated as the arithmetic mean of precipitation sums recorded at a given station. Such an approach was possible due to a relatively even spread of measuring sites.

In the study, particular attention was paid to the extremely high precipitation, which did not occur at single geographic locations (e.g., one station) but was recorded by at least few stations. This allowed us to avoid the discussion about precipitation of a very local nature which causes are fairly complex, most often local, and it is difficult to describe the direct circulation conditions accompanying its formation.

At the same time, separate analyses were carried out for the totals recorded at the individual stations. This involved the extreme events, when the mean areal precipitation exceeded $30 \mathrm{~mm}$. All of the distinguished cases were then analyzed in respect of circulation types. 


\section{Results and discussion}

Spatial differentiation of precipitation totals constantly refers to the relief (Fig. 1). The highest amounts, reaching up to $2000 \mathrm{~mm}$ annually, appear in the mountains; while not more than $700 \mathrm{~mm}$ are typical for the forelands (northern part of the area). Summer precipitation is dominated by the highest amounts of about 100$250 \mathrm{~mm}$ in July. It is worth mentioning that spatial differences in precipitation pattern between the western and eastern parts of the area can be seen (Fig. 1). It is also evident in the high values of extreme precipitation. Therefore a detailed analysis was conducted for the two regions separately.

In the Polish Carpathians, during the period of 1951-2012, totals did exceed $100 \mathrm{~mm}$ at many stations (Table 1), and the highest total occurred in the mountains with the absolute maximum (ever recorded at the synoptic station) on Kasprowy Wierch Mt., where on June 30, 1973, the daily precipitation total was $232 \mathrm{~mm}$. It is worth adding that on the same day, at the neighboring Hala Gąsienicowa Climate Station, there were $300 \mathrm{~mm}$ of rainfall. To this day, this value is considered the highest measured rainfall value in Poland, and it is rather close to the Central European maximum $345.1 \mathrm{~mm}$ reached on July 29, 1897 at the Czech station Nová Louka in Jizerské Hory Mts (Munzar et al., 2011).

Table 1. Events with the highest daily precipitation totals and the associated circulation types by the local Niedźwiedź classification (TN) and the Grosswetterlagen classification $(\mathrm{GWL})$ *

\begin{tabular}{|c|c|c|c|c|c|c|}
\hline $\begin{array}{l}\text { MAX } \\
(\mathbf{m m})\end{array}$ & date & station & $\begin{array}{c}\text { number of } \\
\text { stations with } \\
\text { RR }>100 \mathrm{~mm} \\
\end{array}$ & TN & GWL & $\begin{array}{l}\text { areal } \\
\text { mean } \\
(\mathrm{mm}) \\
\end{array}$ \\
\hline 300.0 & Jun 30,1973 & Hala G. & 6 & $\mathrm{Nc}$ & $\mathrm{HM}$ & 52.3 \\
\hline 224.0 & Jul18, 1970 & Szczyrk & 19 & $\mathrm{Nc}$ & TrM & 83.4 \\
\hline 223.5 & Jul 8, 1997 & Hala G. & 6 & $\mathrm{Nc}$ & $\mathrm{Na}$ & 52.4 \\
\hline 213.0 & Aug 31, 2010 & Szczyrk & 5 & NEc & $\operatorname{TrM}$ & 45.9 \\
\hline 190.8 & Jul 25, 2001 & $\begin{array}{l}\text { Maków } \\
\text { Podh. }\end{array}$ & 1 & $\mathrm{Nc}$ & $\mathrm{BM}$ & 23.2 \\
\hline 173.0 & Jul 18, 1962 & Hala G. & 3 & $\mathrm{NEc}$ & $\mathrm{U}$ & 43.4 \\
\hline 172.8 & May 16, 2010 & Brenna & 10 & NEc & $\operatorname{TrM}$ & 75.3 \\
\hline 169.2 & Aug 21, 1972 & Brenna & 5 & $\mathrm{Nc}$ & TrM & 50.9 \\
\hline 161.7 & Jun 29, 1958 & Szczyrk & 5 & $\mathrm{Nc}$ & $\mathrm{HFa}$ & 64.9 \\
\hline 157.0 & Sep 7, 1996 & Wisła & 2 & $\mathrm{Nc}$ & $\mathrm{HNa}$ & 39.0 \\
\hline 154.1 & Jul 25, 1960 & Brenna & 3 & $\mathrm{Nc}$ & $\mathrm{NWz}$ & 49.0 \\
\hline
\end{tabular}


Having analyzed particular circulation types, it can be stated that the majority of extremely high precipitation totals occurred in cyclone-type situations with airflow from the northern sector (Table 1). This applied basically to $\mathrm{N}$ and $\mathrm{NE}$ directions.

The same patterns can be seen while analyzing areal means. Majority of situations when daily mean areal precipitation totals exceeded $30 \mathrm{~mm}$ happened in cyclonic situation with $\mathrm{N}$ or NE advections and in a cyclonic trough (Fig. 2).

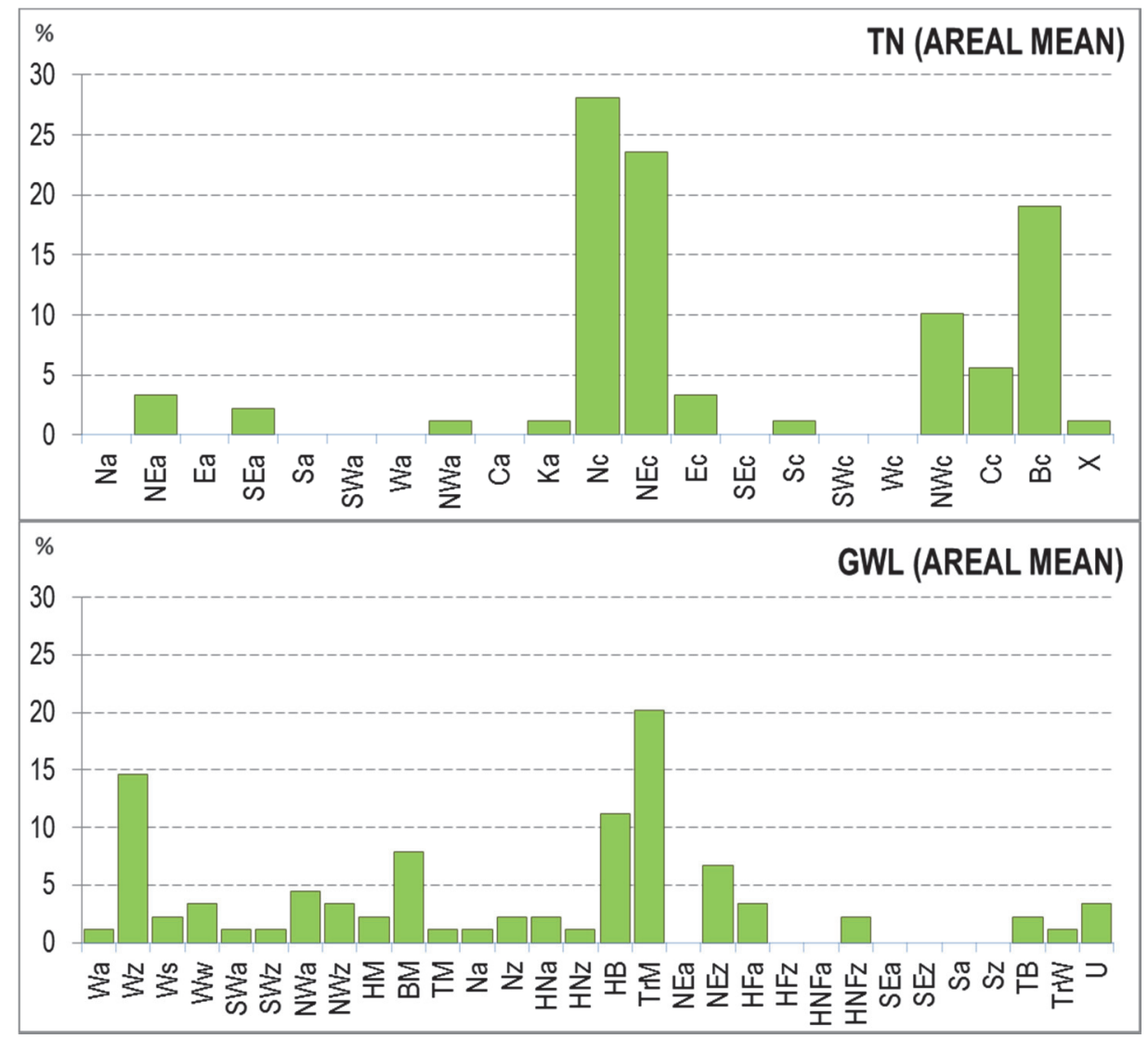

Fig. 2. Frequency of extreme daily precipitation totals over $30 \mathrm{~mm}$ in the Polish Carpathians in particular circulation types.

It is worth mentioning that the maximum daily precipitation totals occurred at only several stations during periods of a stationary low pressure center, and at a slightly higher number of stations during a cyclonic pattern with NE airflow (Fig. 2). 
The circulation background, however, seems to differ spatialy (Fig. 3). For the western part of the area of interest, extreme precipitation is most frequently associated with the beforementioned $\mathrm{Nc}, \mathrm{NEc}$, and also cyclonic through $(\mathrm{Bc})$ situations, whereas to the east, the impact of high pressure system with advection from eastern sector and NW can also be seen (Fig. 3).

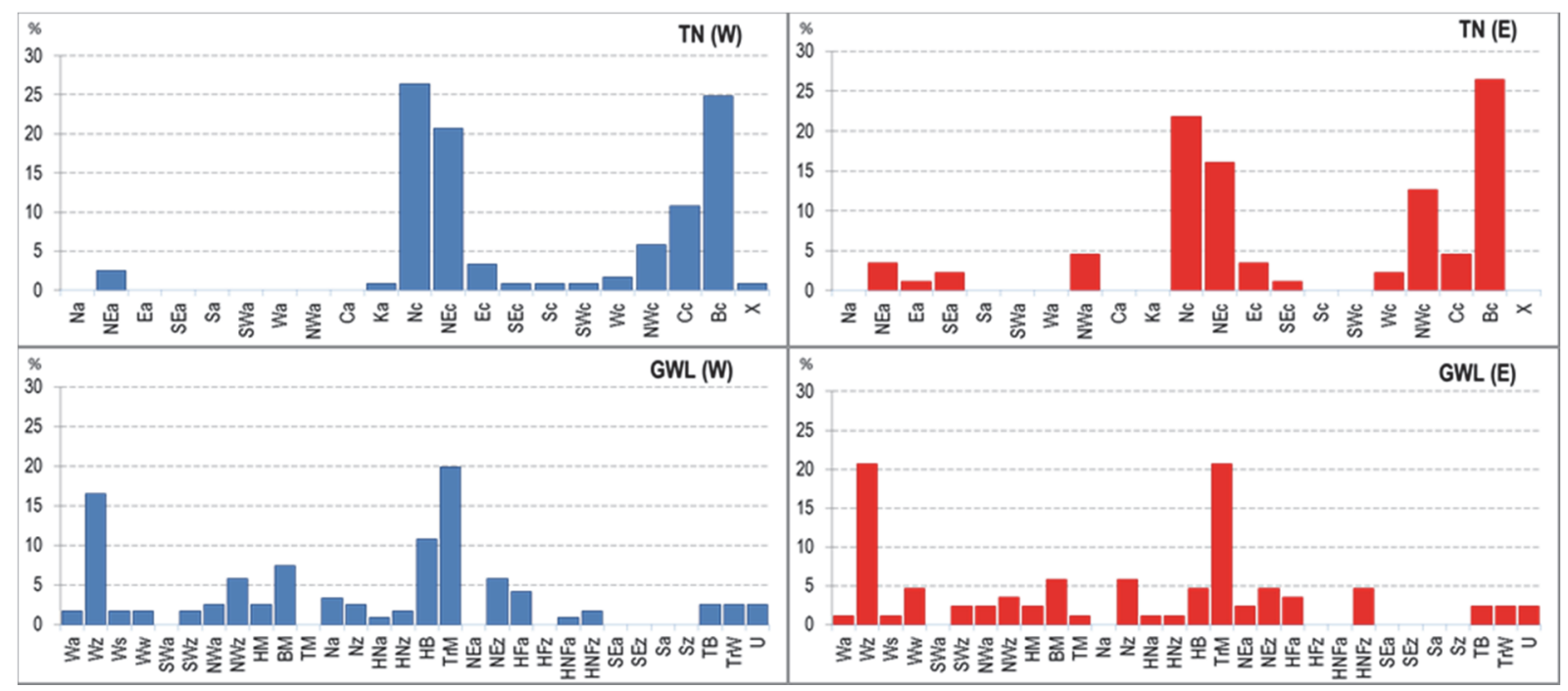

Fig. 3. Frequency of extreme daily precipitation totals over $30 \mathrm{~mm}$ in the western (W) and eastern (E) parts of the Polish Carpathians in particular circulation types.

It is worth mentioning (as it was previously stated) that the amount of precipitation reaching the west is much higher. The mean areal maxima recorded for the region are over $90 \mathrm{~mm}$, while the eastern part does not get more than $56 \mathrm{~mm}$ of rain, what was the maximum for 1966 (Fig. 4).

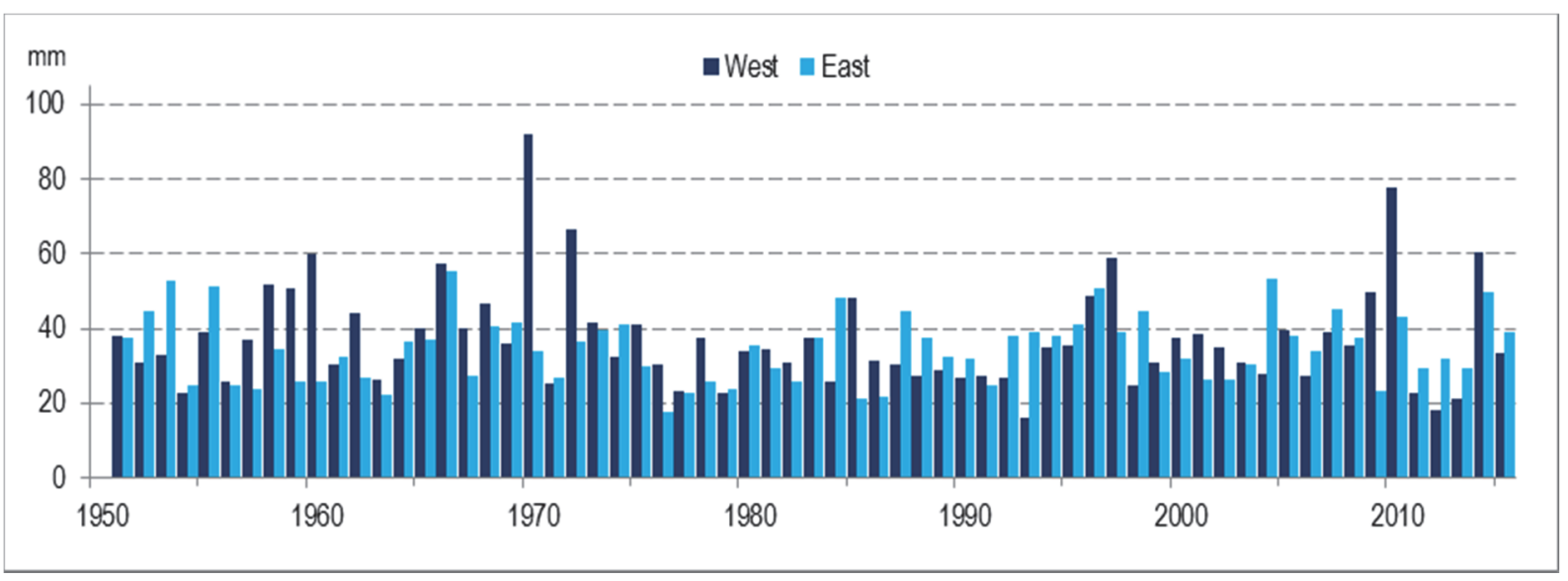

Fig. 4. Extreme daily precipitation totals $(\mathrm{mm})$ - areal mean of western and eastern part of the Polish Carpathians. 
For 68 measuring points, the highest daily mean areal precipitation totals were over $70 \mathrm{~mm}$ in 1970 , more than $60 \mathrm{~mm}$ were recorded in 2010 , but it is shown that while the whole area is taken into consideration, the areal extremes are lower and less frequent (there are some years without aeral mean over $30 \mathrm{~mm}$ -Fig. 5).

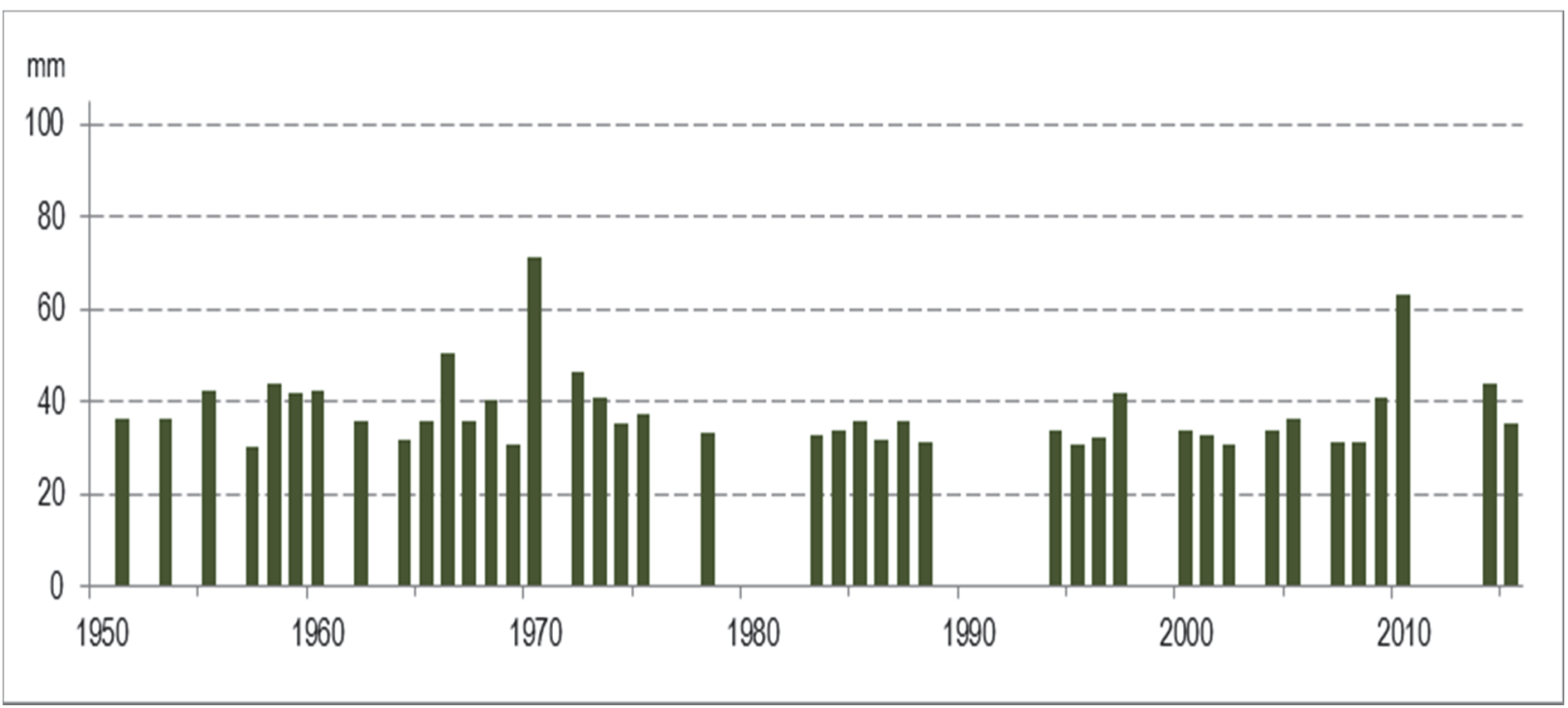

Fig. 5. Extreme daily precipitation totals $(\mathrm{mm})$ - the highest areal mean over $30 \mathrm{~mm}$ is in the Polish Carpathians.

The regularity described above becomes clearly seen with stronger criteria. Days with daily mean areal precipitation exceeding $50 \mathrm{~mm}$ were selected. Table 2 presents the exceptional events when the amount of water provided for each sq. meter was higher than 50 liters. Such an extreme situation happened twice more frequent in the western part of the Carpathians. Also, the relationship between precipitation extremes and strong moisture fluxes from the north was substantially more significant for the western than for the eastern part of Polish Carpathians.

Those distinguished extremes and their circulation background (Table 2) proved also the slight difference in circulation impact along the mountain range in southern Poland. Almost all of the events (except for two) in the western part were associated with Nc, NEc situations, while the role of circulation types in the eastern part is less univocal. There are 6 different types influencing such high daily mean areal precipitation totals (Table 2). 
Table 2. Events with extreme (over $50 \mathrm{~mm}$ ) daily precipitation areal mean in the western and eastern Polish Carpathians and the associated circulation type by TN and GWL classifications

\begin{tabular}{|c|c|c|c|c|c|c|c|}
\hline \multicolumn{4}{|c|}{ West } & \multicolumn{4}{|c|}{ East } \\
\hline $\begin{array}{c}\text { Areal mean } \\
(\mathrm{mm})\end{array}$ & Date & $\mathbf{T N}$ & GWL & $\begin{array}{c}\text { Areal mean } \\
(\mathrm{mm})\end{array}$ & Date & $\mathbf{T N}$ & GWL \\
\hline 103.8 & Jul 18, 1970 & $\mathrm{Nc}$ & $\operatorname{TrM}$ & 66.2 & Sep 06, 1996 & $\mathrm{Nc}$ & $\mathrm{HNa}$ \\
\hline 85.8 & May 16, 2010 & NEc & TrM & 59.0 & Aug 2, 1963 & $\mathrm{Ea}$ & $\mathrm{HFa}$ \\
\hline 70.8 & Jun 29,1958 & $\mathrm{Nc}$ & $\mathrm{HFa}$ & 58.9 & Aug 27, 1966 & $\mathrm{NEc}$ & $\mathrm{HNFz}$ \\
\hline 69.3 & Aug 8, 1997 & $\mathrm{Nc}$ & $\mathrm{Na}$ & 57.1 & Jul 27, 2004 & $\mathrm{Nc}$ & $\operatorname{TrM}$ \\
\hline 68.1 & Aug 21, 1972 & $\mathrm{Nc}$ & TrM & 52.8 & Aug 24, 1953 & $\mathrm{Nc}$ & $\mathrm{Wz}$ \\
\hline 63.6 & Jul 25, 1960 & $\mathrm{Nc}$ & NWz & 52.1 & Jul 18, 1968 & $\mathrm{Cc}$ & $\mathrm{Nz}$ \\
\hline 62.7 & May 29, 1966 & $\mathrm{Nc}$ & $\mathrm{HB}$ & 51.3 & Jun 21, 1955 & $\mathrm{Bc}$ & $\mathrm{Ww}$ \\
\hline 60.9 & Aug 31, 2010 & $\mathrm{NEc}$ & $\operatorname{TrM}$ & 50.2 & Sep 4, 2007 & NWc & NWz \\
\hline 56.9 & Aug 20, 1972 & NEc & $\operatorname{TrM}$ & & & & \\
\hline 55.7 & Jun 30,1973 & $\mathrm{Nc}$ & $\mathrm{HM}$ & & & & \\
\hline 54.6 & Sep 7, 1996 & $\mathrm{Nc}$ & $\mathrm{HNa}$ & & & & \\
\hline 53.2 & Aug 22, 2009 & $\mathrm{Bc}$ & $\mathrm{BM}$ & & & & \\
\hline 52.7 & Aug 8, 1985 & $\mathrm{Nc}$ & $\operatorname{TrM}$ & & & & \\
\hline 52.6 & Jul 18, 1962 & $\mathrm{NEc}$ & $\mathrm{U}$ & & & & \\
\hline 50.9 & Jul 13, 1960 & $\mathrm{NEc}$ & $\mathrm{Wa}$ & & & & \\
\hline 50.6 & Jun 30,1959 & NWc & TrM & & & & \\
\hline
\end{tabular}

As it has already been mentioned, that the information on the circulation of upper level was also used in this work. So far, such an approach has not been fully discussed as no quantitative information was accessible. The data from the reanalyses allowed to investigate the influence of circulation for the whole research period. The analyses of particular cases proved that the data from the 700 or $300 \mathrm{hPa}$ levels does not provide any substantial information. For this reason, only data from the $500 \mathrm{hPa}$ level, which represents mid-tropospheric conditions, was taken into consideration.

As first, the situations determining the highest values of precipitation in the Western Carpathians, i.e., those associated with the advection from the $\mathrm{N}$ sector were investigated. In these cases, the analysis of the direction of the airflow at the $500 \mathrm{hPa}$ level was carried out. It turned out that in mid-troposphere the advection from the southern sector (especially from the $\mathrm{SW}$ ) is observed in instances with most daily totals (about 50\% of all cases) (Fig. 6a). This regularity is noticeable in almost every class of daily mean areal precipitation totals, and it can be observed at individual stations. At the Krakow station, located at the foreland of the Carpathians, the SW direction at the $500 \mathrm{hPa}$ level is even more significant (Fig. 6b). 


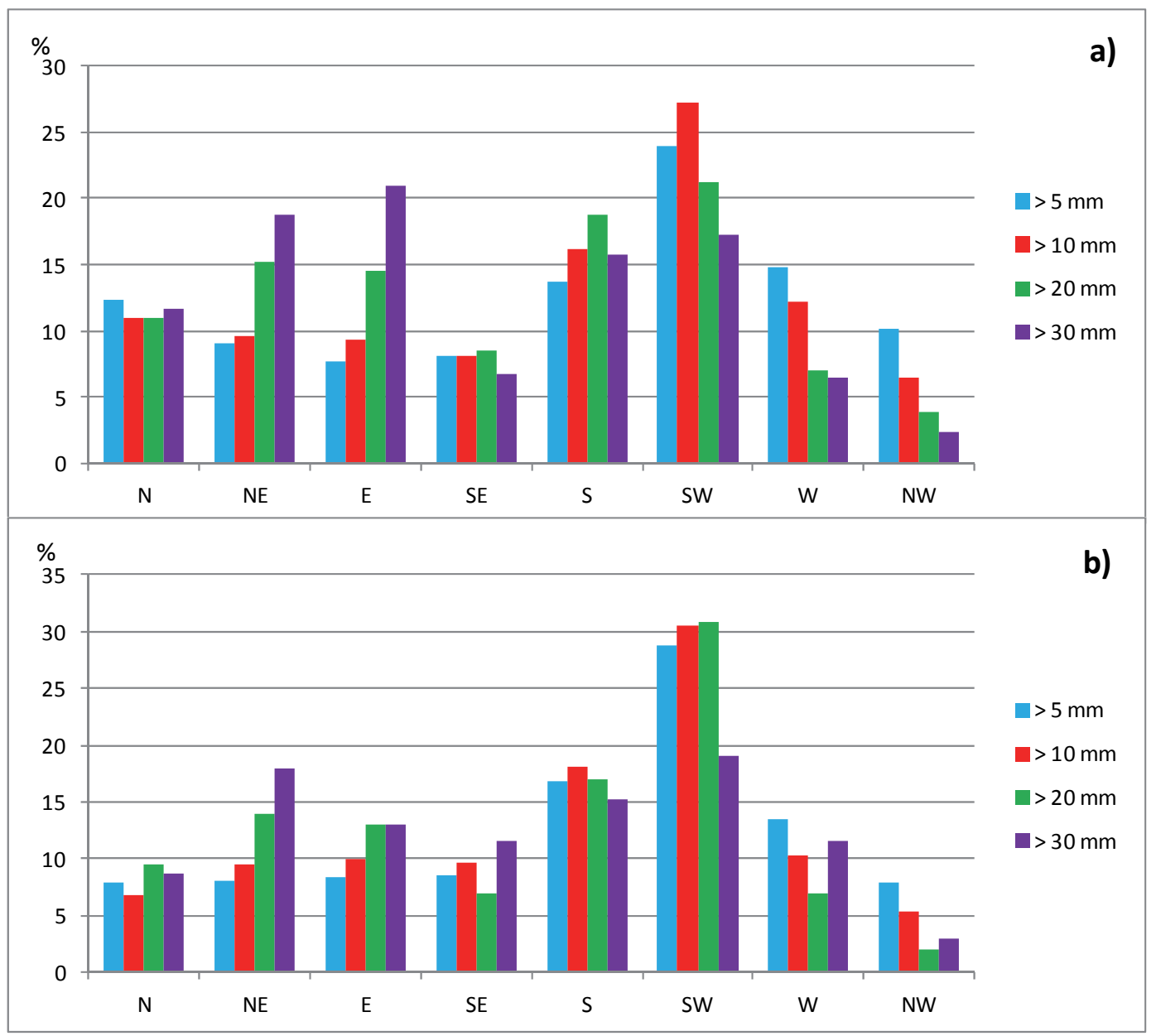

Fig. 6. Frequency of daily precipitation totals over selected thresholds in the particular direction airflows at the $500 \mathrm{hPa}$ level (northern sector airflow at $1000 \mathrm{hPa}$ ) - a) areal mean, b) Krakow station.

Analogous relationships can also be found for other weather stations. It means that both low- and mid-level atmospheric circulation influence high precipitation totals. The impact of local conditions of terrain on heavy rainfalls is significantly smaller than the direction of the airflow in the low- and midtroposphere. This regularity is evident over the whole area, including the areas outside the borders of Poland. The calculations carried out for the two stations in Slovakia expose the same regularity. Fig. 7 shows the frequency of significant precipitation in Poprad, located between the main ranges of the Tatra and the Low Tatra Mountains., in fact situated in the very heart of the Western Carpathians. 


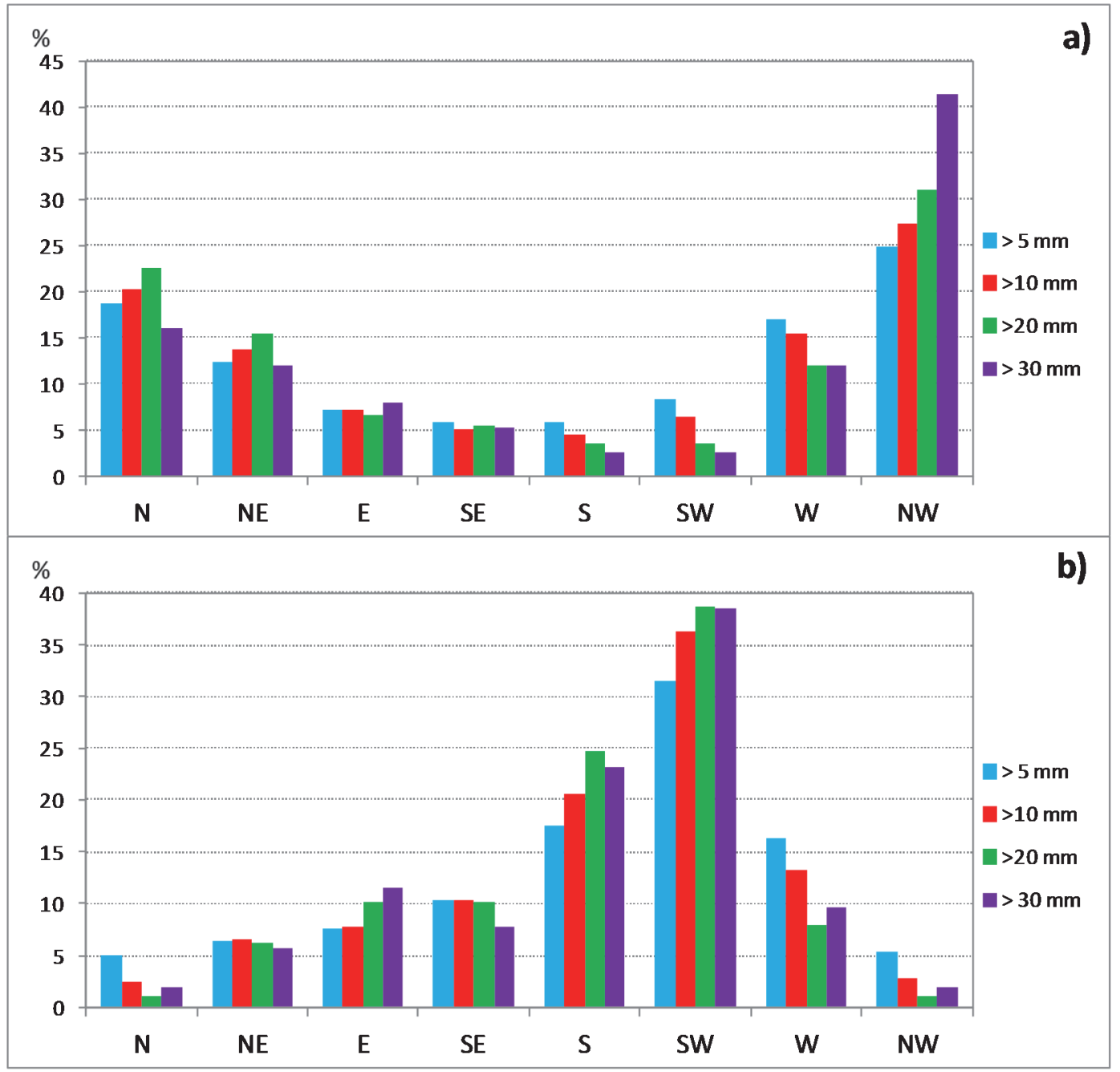

Fig. 7. Frequency of daily precipitation totals over selected thresholds in the particular direction airflows at Poprad station - a) at $1000 \mathrm{hPa}$ level, b) at $500 \mathrm{hPa}$ level during northern sector airflow at $1000 \mathrm{hPa}$.

Significant precipitation totals occur during the northern sector airflow, reaching $60 \%$ of all cases in the lower troposphere (Fig. 7a). The frequency rises up to $70 \%$ when daily totals over $30 \mathrm{~mm}$ are considered. Fig. $7 b$ shows the distribution of precipitation from different directions in the mid-troposphere $(500 \mathrm{hPa}$ level), when in the low-troposphere airflow from the northern sector is observed. Evidently, in all of the ranges of daily precipitation totals, the southern sector is dominant with the SW direction in particular. 


\section{Conclusions}

The study, based on the largest number of measurement data available and compiled for the Polish Carpathians for over a 60-year-long period, shows the differentiation of the highest values of daily precipitation totals. The work proves that practically at every station, the values can exceed $100 \mathrm{~mm}$. From hydrological point of view, for the research area, these can be regarded as extreme values. Precipitation totals recorded within the analyzed period locally reached up to $300 \mathrm{~mm} /$ day, what gave over $100 \mathrm{~mm}$ from the regional point of view (areal mean). However, distinct differences between the western and eastern parts of the Polish Carpathians have been detected.

The analysis confirmed the considerable influence of the atmospheric circulation upon significant precipitation totals including even extreme values. Extreme daily precipitation totals in the Polish Carpathians, which are usually the reasons for floods in southern Poland, are the results of a shallow low-pressure system hovering over -Ukraine (north and north-easterly cyclonic types and trough over Central Europe), often with front system causing cyclone-type airflow from the north and northeast. During the mentioned synoptic situations, cool air masses coming in from the north and northeast cause heavy precipitation events (dynamic rise of air over the mountain barrier increases the amount of precipitation). The analysis confirmed the meaning of the $\mathrm{Vb}$ cyclone track described by van Bebber (distinguished already in 1891) (van Bebber, 1891), which was confirmed in the contemporary studies for Central Europe (e.g., Mudelsee et al., 2004; Seibert et al., 2007).

Analyses with the application of the upper tropospheric data brought some new insight into precipitation extremes causes. It turned out that most cases with significant rains occurred, when the advection in the mid-troposphere was from the southern sector (during the typical N, NE advection in the lower part). Such a situation may be explained with the fact that the collision of warm southerly air, which transports huge amounts of water, with cool air from the north leads to intensive condensation that sometimes results in local thunderstorms with heavy rainfalls. To a certain degree, this situation reminds us of the situation with the so-called Spanish Plume extreme events over the United Kingdom (Webb et al., 2001; Webb, 2011), as well as severe hydrometeorological events over Finland and the Baltic states (e.g., Punkka and Bister, 2005).

The study did not concern very local events with torrential rain of short duration which could produce flash floods. During these events, the maximum intensity of downpours can exceed 100-150 mm within 1-2 hours. As much better time-resolution data is required to conduct such analyses, they are not possible yet due to the lack of the relevant long-time data series.

Acknowledgements: The atmospheric circulation analyses were possible thanks to the NCEP/NCAR reanalysis data. 


\section{References}

Bissolli, P., Friedrich, K., Rapp, J., and Ziese, M., 2011: Flooding in eastern central Europe in May 2010 reasons, evolution and climatological assessment. Weather 66, 147-153.

https://doi.org/10.1002/wea.759

Brázdil, R., Dobrovolný, P., Elleder, R., Kakos, V., Kotyza, O., Květon̆, V., Macková, J., Müller, M., Štekl, J., Tolasz, R., and Valášek, H., 2005: Historical and recent floods in the Czech Republic. Masaryk University in Brno, Czech Hydrometeorological Institute in Prague, Brno-Prague.

Cebulak, E., 1992: Wpływ sytuacji synoptycznej na maksymalne opady dobowe w dorzeczu górnej Wisły Folia Geographica, Ser. Geographica Physica 23, 81-95. (in Polish)

Cebulak, E., and Niedźwiedź, T., 2000: Zagrożenie powodziowe dorzecza górnej Wisły przez wysokie opady atmosferyczne. Monografie Komitetu Gospodarki Wodnej PAN 17, 55-70 (in Polish)

Die Grosswetterlagen Europas. http://www.dwd.de/GWL (assessed May 3, 2016)

Grela, J., Stota, H., and Zieliński, J. (eds.), 1999: Dorzecze Wisły - Monografia powodzi lipiec 1997. Institute of Meteorology and Water Management, Warsaw. (in Polish)

Kašpar, M., Müller, M., and Pecho, J., 2013: Comparison of meteorological conditions during May and August 2010 floods in Central Europe. AUC Geographica 48, 27-34.

https://doi.org/10.14712/23361980.2015.2

Kundzewicz, Z.W., Dobrowolski, A., Lorenc, H., Niedźwiedź, T., Pińskwar, I., and Kowalczak, P., 2012: Floods in Poland. In (ed.: Kundzewicz, Z.W. ) Changes in Flood Risk in Europe. Special Publication No. 10, IAHS Press, Wallingford, Oxfordshire, UK, 319-334.

https://doi.org/10.1201/b12348

Kundzewicz, Z.W. (ed.), 2012: Changes in Flood Risk in Europe. CRC Press.

Kundzewicz Z.W., Stoffel M., Niedźwiedź T., and Wyżga B. (eds.), 2016: Flood Risk in the Upper Vistula Basin. GeoPlanet: Earth and Planetary Sciences, Springer. https://doi.org/10.1007/978-3-319-41923-7

Eupikasza, E. and Niedźwiedź, T., 2015: Wieloletnia zmienność typów cyrkulacji sprzyjających występowaniu wysokich opadów atmosferycznych w Tatrach (1873-2014). In (eds.: Lorenc, H. and Ustrnul, Z.) Klimat a Społeczeństwo i Gospodarka. Polskie Towarzystwo Geofizyczne Oddział Warszawski, Instytut Meteorologii i Gospodarki Wodnej Państwowy Instytut Badawczy, Warszawa: 93-111. (in Polish)

Eupikasza, E., 2016: The Climatology of Air- Mass and Frontal Extreme Precipitation. Springer Atmospheric Sciences, Springer. https://doi.org/10.1007/978-3-319-31478-5

Maciejewski, M., Ostojski, M.S., and Walczykiewicz, T. (eds.), 2011: Dorzecze Wisły - Monografia powodzi maj-czerwiec 2010. Institute of Meteorology and Water Management - National Research Institute, Warsaw (in Polish)

Morawska-Horawska, M., 1971: Meteorologiczne przyczyny powodzi w Polsce południowej w lipcu 1970 roku. Przeglad Geofizyczny 4, 299-315 (in Polish)

Mudelsee, M., Börngen, M., Tetzlaf, G., and Grünewald, U., 2004: Extreme floods in Central Europe over the past 500 years: role of cyclone pathway "Zugstrasse Vb". J. Geophys. Res. 109(D23101),1-21. https://doi.org/10.1029/2004JD005034

Müller, M., Kašpar, M., and Matschullat, J., 2009: Heavy rains and extreme rainfall-runoff events in Central Europe from 1951 to 2002. Nat. Hazards Earth Syst. Sci. 9, 441-450.

https://doi.org/10.5194/nhess-9-441-2009

Munzar, J., Ondráček, S., and Auer, I., 2011: Central European one-day precipitation records. Moravian Geographical Reports 19, 32-40.

Niedźwiedź, T., 2003: Extreme precipitation events on the northern side of the Tatra Mountains. Geogr. Polonica 76, 13-21.

Niedźwiedź, T., 2016: Catalogue of synoptic situations in the upper Vistula river basin (1873.09-2015.12). http://klimat.wnoz.us.edu.pl

Niedźwiedź, T., Lupikasza, E., Pińskwar, I., Kundzewicz, Z.W., Stoffel, M., and Małarzewski, L., 2015: Variability of high rainfalls and related synoptic situations causing heavy floods at the northern foothills of the Tatra Mountains. Theor. Appl. Climatol. 119, 273-284.

https://doi.org/10.1007/s00704-014-1108-0 
Niedźwiedź, T., Twardosz, R., and Walanus, A., 2009: Long-term variability of precipitation series in east central Europe in relation to circulation patterns. Theor. Appl. Climatol. 98, 337-350.

Pavlik, J. and Sandev, M., 1997: Synoptické hodnoceni povětrnostnichsituaci v průběhupovodně v červenci 1997. Meteorologickéz právy 50, 164-171. (in Czech)

Punkka, A.J. and Bister, M., 2005: Occurrence of summertime convective precipitation and mesoscale convective systems in Finland during 2000-01. Month. Weather. Rev. 133, 362-373. https://doi.org/10.1175/MWR-2854.1

Seibert, P., Frank, A., and Formayer, H., 2007: Synoptic and regional patterns of heavy precipitation in Austria. Theor. Appl. Climatol. 87, 139-153. https://doi.org/10.1007/s00704-006-0198-8

Twardosz, R., Cebulska, M., and Walanus, A., 2016: Anomalously heavy monthly and seasonal precipitation in the Polish Carpathian Mountains and their foreland during the years 1881-2010. Theor. Appl. Climatol. 126, 323-337. https://doi.org/10.1007/s00704-015-1570-3

Ustrnul, Z. and, Czekierda, D., 2001: Circulation background of the atmospheric precipitation in central Europe (based on the Polish example). Meteorol. Z. 10(3), 103-111. https://doi.org/10.1127/0941-2948/2001/0010-0103

Ustrnul, Z., D. and Czekierda, 2009: Atlas of extreme meteorological phenomena and synoptic situations in Poland. IMGW, Warszawa, 182.

van Bebber, W.J., 1891: Die Zugstrassen der barometrischen Minima. Meteorol. Z., 8, 361-366.

Webb, J.D.C., 2011: The great summer heatwaves of 1975-1976 in the UK, and some violent storms. Int. J. Meteorol. 36, 255-261.

Webb, J.D.C., Elsom, D.M. and Reynolds, D.J., 2001: Climatology of severe hailstorms in Great Britain. Atmos. Res. 56, 291-308. https://doi.org/10.1016/S0169-8095(00)00081-8

Werner, P.C. and Gerstengarbe, F-W., 2010: Katalog der Großwetterlagen Europas (1881-2009) nach Paul Hess und Helmut Brezowsky, 7. verbesserte und ergänzte Auflage. PIK Report 119. www.dwd.de/GWL 